\title{
Analysis of Simple Mechanism Using MSC Adams
}

Ingrid Delyová, Darina Hroncová, Peter Frankovský

Department of Applied Mechanics and Mechatronics, SjF TU v Košiciach, Letná 9, 04200 Košice, Slovak Republic, Email: ingrid.delyova@tuke.sk, darina.hroncova@tuke.sk, peter.frankovsky@tuke.sk

In addressing the motion of machine parts, machines and equipment it is necessary to first create a kinematic model. Kinematic model of a device schematically captures all its properties which are essential in kinematic analysis. This article deals with kinematic analysis of a simple mechanism executing a rotational movement. We analyzed the movement of its end points. Numerical solution was implemented by classical kinematics using different coordinate systems, while model mechanism has been also modeled and solved in the program MSC Adams. The result of the computer simulation is designation of the searched kinematic parameters and the other required parameters of the solved model. Solutions are time kinematic variables over time, which are shown graphically.

Keywords: Kinematics, Analytical solution, Numerical solution, Simulation

\section{Acknowledgement}

This work was supported by grant projects VEGA No. 1/1205/12 and VEGA No. 1/0937/12 and APVV-0091-11.

\section{References}

[1] BOCKO, J., FRANKOVSKÝ, P., DELYOVÁ, I., PÁSTOR, M. (2011). Kinematics in Examples, SjF TU v Košiciach.

[2] MIKOVA, L., TREBUNA, F., CURILLA, M. (2013). Model of mechatronic system's undercarriage created on the basis of its dynamics, In: Proceedings of the 2013 International Conference on Process Control, Strbske Pleso; Slovakia, pp. 231-234.

[3] HRONCOVÁ, D., BINDA, M., ŠARGA, P., KIČÁK, F. (2012). Kinematical Analysis of Crank Slider Mechanism Using MSC AdamsView, In: Procedia Engineering: MMaMS 2012: Modelling of Mechanical and Mechatronics Systems 2012, Vol. 48, pp. 213-222, Slovakia.

[4] SIVÁK, P., HRONCOVÁ, D. (2012). State-Space model of a mechanical system in MATLAB/Simulink, In: Procedia Engineering: MMaMS 2012: Modelling of Mechanical and Mechatronics Systems 2012, Vol. 48, pp. 629-635, Slovakia.

[5] ŠARGA, P., HRONCOVÁ, D., ČURILLAA, M., GMITERKO, A. (2012) Simulation of electrical system using Bond Graphs and MATLAB/Simulink, In: Procedia Engineering: MMaMS 2012: Modelling of Mechanical and Mechatronics Systems 2012, Vol. 48, pp. 656-664, Slovakia.

[6] FRANKOVSKÝ, P., HRONCOVÁ, D., DELYOVÁ, I., HUDÁK, P. (2012). Inverse and forward dynamic analysis of two link manipulator, In: Procedia Engineering: MMaMS 2012: Modelling of Mechanical and Mechatronics Systems 2012, Vol. 48, pp. 158-163, Slovakia.

[7] MIKOVÁ, L., KELEMEN, M. (2012). Model of elements of the hydraulic control system for biaxial tensile test, In: Procedia Engineering: MMaMS 2012: Modelling of Mechanical and Mechatronics Systems 2012, Vol. 48, pp. 420-427, Slovakia.

[8] ROUD, P., ČESÁKOVÁ, I., SKLENIČKA, J., ZETEK, M., KOŽMÍN, P. (2012). Applications for efficiency proposal monolith. twist drill in the CATIA V5, In: Strojírenská technológie, 2012, Vol. XVII., No. 1, 2, pp. 96-101.

[9] SEGLA, S., OREČNÝ, M., TRIŠOVIČ, N. (2013). Semiactive seat suspension with a vibration absorber, In: Manufacturing Technology, Vol. 13, No. 4, pp. 534-539, ISSN 1213-2489.

[10] SEGLA, S., OREČNÝ, M., TRIŠOVIČ, N. (2013). Passive seat suspension with a vibration absorber, In: Manufacturing Technology, Vol. 13, No. 4, pp. 530-534, ISSN 1213-2489.

[11] SVOBODA, M, SOUKUP, J. (2013). Dynamic Measurement of Four-Axle Railway Wagon, Manufacturing Technology, Vol. 13, No. 4, pp. 552-558, ISSN 1213-2489

[12] http://www.mscsoftware.com/product/adams

[13] http://www.diva-portal.org/smash/get/diva2:531245/FULLTEXT01 